\title{
Effect of prolong consumption of crude Aloe barbadensis (Aloe vera) gel on haematological indices in rats
}

\author{
C.O. $\mathrm{Nku}^{1}$, O.E. Ofem ${ }^{1}$, U.A. Okon ${ }^{2}$ \\ ${ }^{1}$ Department of Physiology, College of Medical Sciences, University of Calabar, Nigeria, ${ }^{2}$ Department of Physiology, College of Medical \\ Sciences, University of Uyo, Nigeria
}

\section{A B S T R A C T}

Background: Aloe vera is a succulent perennial plant that belongs to the liliaceae family and to a large family called xeroids. It is a magical plant with vast healing properties, but there is paucity in scientific literature on it effects on haematological parameters. The effect of persistent consumption of crude aqueous extract of Aloe vera on haematological indices of albino Wistar rats was investigated in this study. Methods: Twenty four rats were randomly assigned into three groups of eight rats each. Group 1 (control) received $0.26 \mathrm{~mL}$ of normal saline o.p. Group 2 received $0.26 \mathrm{~mL}$ of aloe vera extract for 2 weeks while group 3 received $0.26 \mathrm{~mL}$ of aloe vera extract for 4 weeks p.o. once daily. All animals receiveddrinking water and normal rat chow ad libitum. Results: Results revealed that the control group had a mean PCV of $37.50 \pm 0.98 \%$; $\mathrm{Hb}, 11.40 \pm 0.39 \mathrm{~g} / \mathrm{dL} ; \mathrm{RBC}, 6.91 \pm 0.35 \times 10^{6} \mathrm{cells} / \mu \mathrm{L} ; \mathrm{WBC}, 4.36 \pm 0.54 \times 10^{3} \mathrm{cells} / \mu \mathrm{L}$ and platelet count, $670.13 \pm 41.01 \times 10^{3} \mathrm{cells} / \mu \mathrm{L}$. These blood parameters were not significantly different in group 2 animals compared with controls, but were significantly higher in group 3 rats compared with controls. Differential WBC counts were as follows for control values: neutrophils, $23.25 \pm 2.39 \%$; lymphocytes, $72.88 \pm 2.55 \%$; monocytes, $0.13 \pm 0.13 \%$; eosinophils, $3.00 \pm 0.71 \%$ and basophils, $0.13 \pm 0.12 \%$. Lymphocytes were significantly $(p<0.05)$ higher in group 3 compared with control group. Conclusion: Aloe vera extract contains phytochemicals that boost blood parameters and immunity on prolong consumption.

Key words: Aloevera gel, blood cells, rats

\section{INTRODUCTION}

Aloe vera is a succulent perennial plant that belongs to the liliaceae family and to a large family called xeroids. ${ }^{1,2}$ It grows wild in Madagascar and large portion of the African continent. The genius contains at least 324 species of herbs, shrubs and trees primarily in African, with some in Madagascar and the Arabian Pennisula, 3,4 of the over 324 species, only four are recognized as being of nutritional value to humans and animals. Aloe barbadensis miller species is significantly top of these four species. ${ }^{5}$ It is a popular house plant and has a long history as a multipurpose folk remedy. ${ }^{6}$ Several names have been ascribed to it relative to its numerous properties and uses which include names like "the potted physician" the wind of heavens and "the medicine plant". 7,8
Access this article online Website:

http://nepjol.info/index.php/AJMS DOI: 10.3126/ajms.v6i2.11106

\section{Address for Correspondence:}

Dr. O. E. Ofem, Department of Physiology, College of Medical Sciences, Univeristy of Calabar, Nigeria.

E-mail: ofemo2003@yahoo.com; Phone: +2348055929850

The aloe vera contains 96 percent water and the remaining 4 percent formed by a mixture of more than 20 substances such as anthraquinone, glycosides, resin, salicylates, glucomannan, enzymes, minerals, acemannan, ${ }^{9}$ sterols and glycoprotein. ${ }^{10}$ Other active ingredients include vitamins such as vitamins $\mathrm{A}, \mathrm{C}, \mathrm{E}, \mathrm{B}_{1}, \mathrm{~B}_{2}, \mathrm{~B}_{5}, \mathrm{~B}_{6}$, and $\mathrm{B}_{12}{ }^{11}$

Reports indicate that aloe exhibit immune boosting activity and the gel is thought to speed recovery from wounds by enhancing the activity of macrophages and fibroblasts. ${ }^{12,13}$ In recent decades, there has been rising health claims on the effectiveness of aloe vera in nearly all aspects of body function. ${ }^{14-17}$ This has led to the increase use of aloe vera especially by alternative medical practitioners. However, few studies have demonstrated its influence on the haematological system. 


\section{MATERIALS AND METHODS}

\section{Experimental plant}

We obtained fresh aloe vera plant from a local market in Calabar, Nigeria. Dr. Owolabi of Department of Botany, University of Calabar, Nigeria identified it as Aloe barbadensis miller.

\section{Experimental animals}

Twenty four (24) female albino Wistar rats weighing between $250 \mathrm{~g}$ to $270 \mathrm{~g}$ obtained from the animal house of Pharmacology Department, University of Calabar, Nigeria were used for this study. The animals housing maintained at controlled environmental temperature and a 12 hour dark and light.

\section{Preparation of crude aloe vera gel}

The fleshy leaves were plucked from the nodes and washed with clean water at room temperature. They were sliced open with a clean sharp kitchen knife alone the mid vein, exposing the gel which was then scraped into a container and homogenized. The resultant crude extract of aloe vera gel was stored in a refrigerator at $-4^{\circ} \mathrm{C}$ afterwards.

\section{Experimental design}

Twenty four albino Wistar rats were randomly assigned into 3 groups of 8 rats each and kept in separate cages. Group 1 (control) was administered with $0.26 \mathrm{~mL}$ of normal saline. Group 2 (subchronic group) received $0.26 \mathrm{ml}$ of aloe vera gel orally and once daily for 2 weeks. Group 3 received $0.26 \mathrm{ml}$ of aloe vera gel orally and once daily for 4 weeks. All the animals received normal rat feed and drinking water ad libitum.

The administered dose $(0.26 \mathrm{ml})$ of aloe verawas derived from a log dose response curve conducted on aloe vera where an $\mathrm{ED}_{50}$ value of $0.1 \mathrm{ml} / 100 \mathrm{~g}$ was obtained. ${ }^{18}$

\section{Collection of blood samples}

After the expiration of the feeding regimens, the animals were made unconscious and blood was collected via cardiac puncture under chloroform inhalation in a desiccator. About $4 \mathrm{ml}$ of blood was obtained from each animal into a well labelled capped EDTA (ethylene diamine tetra acetate) sample bottles. Samples were immediately used for the estimation of the different haematological parameters.

\section{Analysis of blood samples}

Red blood cell count, total white blood cell count, packed cell volume (PCV), and differential WBCs were estimated using standard methods ${ }^{19}$ while haemoglobin concentration was also determined by the standard method. ${ }^{20}$ Mean corpuscular volume (MCV), mean corpuscular hemoglobin $(\mathrm{MCH})$ and mean corpuscular hemoglobin concentration (MCHC) were calculated using standard formula.

\section{RESULTS}

Comparison of RBC count, PCV, Hb, total WBC count and platelet count among the different experimental groups

The control group had the following mean values: RBC, $6.91 \pm 0.35 \times 10^{6}$ cells $/ \mathrm{mm}^{3} ;$ PCV, $37.50 \pm 0.98 \%$; $\mathrm{Hb}, 11.40 \pm 0.39 \mathrm{~g} / \mathrm{dl} ; \mathrm{WBC}, 4.36 \pm 0.54 \times 10^{3} \mathrm{cell} / \mathrm{mm}^{3}$, and platelet count, $670.13 \pm 41.01 \times 10^{3} \mathrm{cells} / \mathrm{mm}^{3}$. RBC count, PCV, Hb, WBC and platelet counts of group 2 animals were not significantly different from these control values. On the other hand, they were significantly $(\mathrm{p}<0.05)$ higher in group 3 animal compared with the control, (Table 1).

Comparison of absolute values of red blood cells among the different experimental group

As summarized in Table 2 , the mean values of $\mathrm{MCV}, \mathrm{MCH}$ and MCHC in the control group were $54.27 \pm 0.72 \mathrm{fl}, 16.50 \pm 0.20 \mathrm{pg}$, and $30.40 \pm 0.08 \mathrm{~g} / \mathrm{dl}$ respectively. The MCV was significantly $(\mathrm{p}<0.05)$ lower in group 2 compared with control. $\mathrm{MCH}$ and $\mathrm{MCHC}$ of both groups 2 and 3 were not significantly different among the groups.

Comparison of absolute values of differential white blood cell count among the different experimental group

The differential WBC count of the different experimental groups are shown in Table 3. The mean counts in the control group were $23.25 \pm 2.29 \% ; 72.88 \pm 2.55 \%$; $0.13 \pm 0.13 \% ; 3.00 \pm 0.71 \%$ and $0.13 \pm 0.12 \%$ for

\begin{tabular}{|c|c|c|c|c|c|}
\hline Variable & RBC count $\left(\times 10^{6} / \mathrm{mm}^{3}\right)$ & Hb conc. (g/dl) & PCV (\%) & Platelets $\left(\times 10^{3} / \mathrm{mm}^{3}\right)$ & WBC $\left(\times 10^{3} / \mathrm{mm}^{3}\right)$ \\
\hline Control & $6.91 \pm 0.35$ & $11.40 \pm 0.39$ & $37.50 \pm 0.98$ & $670.13 \pm 41.01$ & $4.36 \pm 0.54$ \\
\hline Group 2 (Subchronic) & $7.54 \pm 0.38$ & $11.78 \pm 0.42$ & $39.00 \pm 0.87$ & $694.00 \pm 57.06$ & $5.75 \pm 0.89$ \\
\hline Group 3 (Chronic) & $8.12 \pm 0.30^{*}$ & $12.89 \pm 0.54^{*}$ & $42.30 \pm 0.81 *$ & $805.38 \pm 34.56^{* *, b}$ & $6.26 \pm 0.68^{* *}$ \\
\hline
\end{tabular}


neutrophils, lymphocytes, monocytes, eosinophils and basophilsrespectively. Neutrophils and eosinophils were slightly reduced in groups 2 and 3 compared with control while lymphocytes were significantly $(p<0.05)$ increased in group $3(80.50 \pm 1.35 \%)$ compared with control group.

\section{DISCUSSION}

The determination of haematological indices provides information about the general blood picture and the immune system. From this study, the sub-chronic consumption of crude aloe vera gel by rats has been observed to cause insignificant increases in $\mathrm{RBC}, \mathrm{Hb}, \mathrm{PCV}$, total WBC counts, MCV, MCH, MCHC and differential WBC counts, but chronic administration of the extract increased significantly the RBC count, $\mathrm{Hb}, \mathrm{PCV}$, total WBC and lymphocyte counts in rats.

This increase might have been due to the reported stimulation of the bone marrow by aloe vera gel $^{7}$ leading to increased erythropoiesis. It could belinked to stimulation of the growth and differentiation inducers such as the interleukins ${ }^{21,7}$ which help to induce the growth and differentiation of the RBCs. ${ }^{22}$ In addition, aloe vera is known to contain vitamin like $\mathrm{A}, \mathrm{C}, \mathrm{E}, \mathrm{B}_{1}, \mathrm{~B}_{2}, \mathrm{~B}_{5}, \mathrm{~B}_{6}$, and $\mathrm{B}_{12}{ }^{11}$ and minerals such as iron, copper, folic acid etc. ${ }^{23}$ which are essential elements for the formation of blood cells. ${ }^{24}$

The observed increase in the WBC count following the administration of crude aloe gel is in line with previous studies. Researchers have demonstrated that the polysaccharides and acemannan, in the gel stimulate the formation of all types of WBCs from both the spleen and bone marrow with the effect being specific for the generation of the T-lymphocyte. ${ }^{25,26}$ This probably is

\begin{tabular}{|c|c|c|c|}
\hline Variable & $\operatorname{MCV}(\mathrm{fl})$ & $\mathrm{MCH}(\mathrm{pg})$ & MCHC (g/dl) \\
\hline Control & $54.27 \pm 0.72$ & $16.50 \pm 0.20$ & $30.40 \pm 0.08$ \\
\hline Group 2 (Subchronic) & $50.40 \pm 0.89^{*}$ & $15.49 \pm 0.19$ & $30.74 \pm 0.09$ \\
\hline Group 3 (Chronic) & $52.09 \pm 0.56$ & $15.87 \pm 0.23$ & $30.47 \pm 0.10$ \\
\hline
\end{tabular}

the reason for the observed increase in lymphocyte count in the chronic group. Acemannans stimulate immunologically active interleukins and interferons which induce growth of the cells and boost the immune system of which the RBCs are central. ${ }^{27}$ Hence, increase production of interferons, interleukins and other mediators of the immune system through stimulation of macrophages activity is another probable reason for increase in blood cells produced by extensive ingestion of aloe vera gel.

Aloe vera gel was observed to decrease the number of neutrophils and eosinophils in this study, this may be due to interference of aloe emodin and aloin (barbaloin) present in the crude gel with processes of activated polymorphonuclear white blood cells has been reported. ${ }^{28,29}$ Although, the mechanism by which this occur in not well understood.

The increase in lymphocytes and monocytes counts could be linked mainly to the immune boosting activities of the gel constituents, since they are the major cells of the immune system. ${ }^{30}$ It has earlier been demonstrated that aloe vera gel increases production of lymphocytes and macrophages ${ }^{31}$ and also stimulates lymphocyte cell division (blastogenesis). ${ }^{32}$

Oral administration of aloe vera and $\beta$-glucanhas been observed to affect various aspects of the canine immune system, including the effects on haematologic parameters, the composition of lymphocyte subsets, and serum immunglobulins. ${ }^{33-35}$

The findings demonstrate that aloe vera and $\beta$-glucan may stimulate both cellular and humoral immune responses after vaccination in dogs.

\section{CONCLUSION}

Persistent consumption of aloe vera gel increases $\mathrm{Hb}$ concentrations, PCV, RBC, platelets, total WBC counts, as well as lymphocytes count in rats. This action of Aloe vera extract is probably due to its phytochemical constituents like Acemannans that stimulate interleukins and interferons which induce cells growth. It therefore implies that, in human prolonged consumption of aloe

\begin{tabular}{|c|c|c|c|c|c|}
\hline Variable & Neutrophils (\%) & Lymphocytes (\%) & Monocytes (\%) & Eosinophils (\%) & Basophils (\%) \\
\hline Control & $23.25 \pm 2.39$ & $72.88 \pm 2.55$ & $0.13 \pm 0.13$ & $3.00 \pm 0.71$ & $0.13 \pm 0.12$ \\
\hline Group 2 (Subchronic) & $20.00 \pm 1.68$ & $76.75 \pm 2.09$ & $0.00 \pm 0.00$ & $1.88 \pm 0.44$ & $0.13 \pm 0.12$ \\
\hline Group 3 (Chronic) & $21.13 \pm 2.97$ & $80.50 \pm 1.35^{*}$ & $0.38 \pm 0.18$ & $2.25 \pm 0.55$ & $0.13 \pm 0.12$ \\
\hline
\end{tabular}


vera gel could boost blood parameters and immunity, and could be useful to anaemic and immune-suppressed patients or as blood tonic.

\section{ACKNOWLEDGMENT}

The authors of this article wise to acknowledge the assistance of Mr. Edetedet Umoh of the Department of Physiology, University of Calabar, Nigeria for helping to breed the rats used for this studies, he was also of immense benefit during the period of sacrifice and blood collection. Dr. Obem Okwari, the Chief Technology of Physiology Department, University of Calabar, Nigeria is also acknowledged for analysing the blood parameters and also approving the instruments used during the experiment.

\section{REFERENCES}

1. Eshun $\mathrm{K}$ and $\mathrm{He} \mathrm{Q}$. "Aloe Vera: $\mathrm{A}$ Valuable Ingredient for the Food, Pharmaceutical and Cosmetic Industries- A Review". Critical Reviews in Food Science and Nutrition 2004; 44 (2): 91-96.

2. Ramachandra CT and Srinivasa Rao P. Processing of Aloe Vera Leaf Gel: A Review. American Journal of Agriculture and Biological Sciences 2008; 3(2): 502-510.

3. Boudreau MD and Beland FA. "An Evaluation of the Biological and Toxicological Properties of Aloe Barbadensis (Miller), Aloe Vera". Journal of Environmental Science and Health Part C 2006; 24: 103-154.

4. Akinyele BO and Odiyi AC. "Comparativestudy of the vegetative morphology and the existing taxonomic status of Aloe vera L." Journal of Plant Sciences 2007; 2 (5): 558-563.

5. Davis RH, Di Donato JJ, Haetman GM and Haas RC. Anti-inflammatory and wound healing activity of a growth substance in aloe vera. Journal of American Pediatric Association1994; 84:77-81.

6. Darokar MP, Rai R, Gupta AK, Shasany AK, Rajkumar S, Sunderasan V, et al. "Molecular assessment of germ plasm diversity in Aloe spp. using RAPD and AFLP analysis". Journal of Medicine and Aromatic Plant Sciences 2003;25(2): 354361.

7. Atherton P. Aloe vera revised. British Journal of Phytotherapy 1997;4(4):176-183.

8. Lyons G. "The Definitive Aloe vera, vera". Huntington Botanic Gardens. Archived from the original on 25 July 2008. Retrieved 2014-07-11

9. Prajapati M, Patel PS and Vyas PJ. Phytochemical Analysis of Aloe Vera and Study of Mixing Antibiotic with Aloe Vera and Its Antibacterial Activity. Asian Journal of Biochemistry and Pharmaceutical Research 2011; 2 (1):473-478.

10. Yebpella GG, Hammuel C, Adeyemi HMM, Magomya AM, Agbaji AS and Shallangwa GA. Phytochemical screening and a comparative study of antibacterial activity of Aloe vera green rind, gel and leaf pulp extracts. Int Res J Microbiol 2011;2(10):382386.

11. Pierce RF. Comparison between the nutritional content of the aloe gel from conventional and hydroponically grown plants. Erde Int 1993;1:37-38.

12. Heggers JP, Pelley RP and Robson MC. Beneficial effect of aloe in wound healing. Phytotherapy Research 1993; 7:S48-S52.
13. Davis $\mathrm{RH}$. Aloe vera: A scientific approach. Journal of the American Paediatric Association 1998; 89:621-627.

14. Boudreau MD and Beland FA. "An Evaluation of the Biological and Toxicological Properties of AloeBarbadensis (Miller), Aloe Vera". Journal of Environmental Science and Health Part C, 2006, 24: 103-154.

15. Adams M. The Aloe Vera Miracle. Truth Publishing International, Ltd. 2007

16. Radmilo A. "Aloe", Aloe Vera Community of Canada. February 20 , 2007, http://www.Aloeveracanada.ca/about_av.html. Retrieved $13 / 04 / 2012$

17. Gajendra PS, Anju R, Divyarajsinh AZ, Monika S, Anurag S and Sunil R. Aloe. barbadensis Miller a valuable ingredient for traditional uses and toxicological properties-A Review. International Journal of Reconstruction and Biotechnology 2013; 1(1): 48-54.

18. Ani EJ, Ibu JO, Ofem OE and Onwuelingo S. Gastric acid secretion induced by aloe barbadensis (aloe vera) gel in rats. West African Journal of Biological Sciences 2005; 16:15-24.

19. Nna VU, Akpan UP, Ofem EO and Osim EE. Crude Aloe vera gel Reverses Polyphagia, Polydipsia, Hyperglycemia and Increases Body Weight in Alloxan - Induced Diabetic Rats. British Journal of Medicine and Medical Research 2013; 3 (4), 2306-2316.

20. Alexander RR and Griffiths JM. Haemoglobin determination by the cyanomethaemoglobin method. In: Basic Biochemistry Methods. $2^{\text {nd }}$ ed. John Wiley and Sons.Inc. New York. 1993; 188-1289.

21. Peng SY, Normen J, Curtin G, Corrier D, Mc Daniel HR and Busbee DL. Decreased mortality of norman murine sarcoma in mice treated with immunomodulator, Acemanna. Molecular Biotherapy1991; 3(2):79-87.

22. Guton AC and Hall JE. (2000). Textbook of Medical Physiology. $10^{\text {th }}$ ed. W. B. Saunders Company, Philadelphia; 2000.

23. Shelton RM. Aloe vera. Its chemical and therapeutic properties. International Journal of Dermatology1991; 30:679-683.

24. Ibu JO. Physiology of blood emergency medical services. Jos University Press. Pp. 23-24; 2005.

25. Egger S, Brown GS and Keyley LS. Studies on optimal dose and administration schedule of a haemopoietic stimulatory beta-(1-4)-linked mannan. International Journal of Immunopharmacology 1996; 18:113-126.

26. Wombe $\mathrm{D}$ and Helderman JH. Enhancement of alloresponsiveness of human lymphocytes by acemannan (Carrisyn TM). International Journal of Immunopharmacology 1988;10:967-974

27. Merriam EA, Campell BD, Flood LP, Welsh CJP, Mc Daniel HR and Busbee DL. Enhancement of immune function in rodents using a complex carbohydrate which stimulates macrophages secretion of immune-reaction cytokines. In: Advance in Anti-aging Medicine.1,181-203. New York: Mary Ann Liebert, Inc; 1996.

28. Hart LA, Enckevocrk H, von Dijkh Z, Zant R, de Silva KT and Labadie RP. (1998). Two traditionally and chemically distinct immunomodulatory compounds in the gel of aloe vera. Journal of Ethnopharmacology1998; 23:61-71.

29. Avila H, Rivero J, Harera F and Frank G. Cytotoxicity of a low molecular weight fraction from aloe vera (Aloe barbadensis miller). Toxicon1997; 35:1423-1430.

30. Ulbricht C, Armstrong J, Basch E, Basch S, Bent S, Dacey C, et al. An evidence-based systematic review of Aloe vera by the Natural Standard Research Collaboration. J Herb Pharmacother 2007;7(3-4):279-323

31. Mc Daniel HR, Perkins S and Analley BH. A clinical pilot study 
using carrisyn syndrome (AIDS). American Journal of Clinical Pathology 1997; 88:534

32. Winters WD. Lymphocyte stimulation by newly identified aloe lectinmitogens. Advances in New Drug Development 1991; 40:391-397.

33. Nelson RW and Couto CG. Small Animal Internal Medicine. Third ed. Mosby Inc. Philadelphia; 2003.
34. Schultz RD. Duration of immunity for canine and feline vaccines: A review. Veterinary Microbiology 2006; 117: 75-79.

35. Nuri A, Nazmi $Y$ and Zahid TA. Immunostimulatory Effects of Aloe vera and $\beta$-Glucan on Cellular and Humoral Immune Responses Following Vaccination with Polyvalent Vaccines in Dogs. Kafkas Univ Vet Fak Derg 2010;16(3): 405-412

\section{Authors Contribution:}

CON - Designed the study, wrote the initial draft of the manuscript; OEO - Analysed the data and edited the manuscript; UAO - Reviewed the manuscript and contributed to the study design.

Source of Support: University of Calabar Senate Research Grant. Conflict of Interest: None declared. 